\title{
Shalva Tabatadze
}

Ivane Javakhishvili Tbilisi State University

Associate Professor at East European University, Georgia

\section{Textbooks for Minority Schools of Georgia; Problems and Challenges}

\begin{abstract}
This article explores research results on challenges and problems of schools textbooks for nonGeorgian schools in Georgia. The desk research and focus group discussions research methods were utilized in the study. The research revealed interesting patterns on problems of schools textbooks for minority schools, specifically: a) the problem of quality of translation of the textbooks; (b) The school textbooks contain stereotyped material as well as diversity of Georgia and intercultural aspects are not reflected in school textbooks. Some paragraphs in schools textbooks contain discriminative elements toward different minorities. (c) The portion of the material in the state language in bilingual textbooks is difficult for pupils to understand because neither the pupils and teachers nor parents speak the state language well enough to incorporate the material in teaching and learning process. The research findings have important practical and educational implications. The author argues that, it is crucially important to make the policy changes for improvement of school textbooks for minority schools in order to achieve the goal of civil integration of ethnic minorities through educational system.
\end{abstract}

\section{Introduction}

Georgia is located on the Black Sea's eastern coast at the crossroads of Western Asia and Eastern Europe. Georgia borders Armenia, Azerbaijan, Russia, and Turkey. Georgia has a population of about 4,585,874 (Tabatadze, 2015). Georgia is a multiethnic country. According to the 2002 census, ethnic Georgians make up $83.8 \%$ of the total population, while other ethnic groups account for $15.2 \%$. A complicating factor with regard to ethnic minorities is that there are big differences between minority groups in terms of population and types of settlement (compact or dispersed), and the level of their integration into the country's social and political life. Ethnic enclaves (compact settlements of minorities) are situated in four regions of Georgia: Abkhazia, South Ossetia, Kvemo Kartli, and SamtskheJavakheti. There is also a Kist (ethnic group related to Chechens) community in Kakheti's 
Pankisi Gorge, though they make up only a small percentage of the population there (Tabatadze et al. 2008). Apart from the enclaves, some ethnic groups are dispersed over the entire country, such as Russians, Greeks, Kurds, Jews, Yazidis, Assyrians, Ukrainians (Gabunia, 2014a). It is noteworthy that these ethnic groups are not homogenous (Gabunia, 2014b). For instance, the Greek community consists of two parts: Turkish-speaking and Greek-speaking. Azeri residents of Shida Kartli (central Georgia) greatly differ from their fellow Azeri residents of Kvemo Kartli (southern Georgia). Namely, they have different education: the former are educated in Georgian, the latter in Azeri (Tabatadze, 2009)

Civil integration is one of Georgia's strategic political priorities. According to the Georgian government's statements, the national education system is the cornerstone of successful civil integration (Tabatadze, 2009). The government issued Order № 348 on May 8, 2009, to approve the National Concept for Tolerance and Civic Integration and the Action Plan for 2009-2014. According to this act, the Office of the State Minister of Georgia for Reintegration was given the task to develop a policy for national minority related issues, and coordinate and report to the Government and the President's Council (Office of State Minister For Reconcilation and Civic Equality,
Assessment Report, 2014). Civil integration through education and multilingual education is considered as an important tool to achieve the integration of ethnic minorities (Government of Georgia, Concept and Action Plan on Tolerance and Civil Integration 2009-2014, 2009).

\section{Ethnic Minority Education in Georgia}

The educational system in Georgia is comprised of preschool, general, and tertiary education, as well as secondary vocational education and training. General education is offered in three levels: primary education (grades 1 to 6); basic education (grades 7 to 9) and secondary education (grades 10 to 12). The current general education system is based on the Law on General Education adopted in April 2005. The Law is the main provision of the principle rights and freedoms of students, their parents, and teachers. According to Georgian legislation every general education school in Georgia is recognized as an independent legal entity of public law. There are 2084 public and 230 private schools in Georgia with approximately $560 \quad 000$ school students (Tabatadze and Gorgadze, 2014) There are 213 non-Georgian language schools and 77 nonGeorgian language sectors in Georgia today with 59000 of students' population (Tabatadze and Gorgadze, 2014). 
Table, 1, Non-Georgian public schools by region, 2013

\begin{tabular}{|l|l|l|l|l|}
\hline & Azerbaijani & Russian & Armenian & Total \\
\hline Region & & & & 0 \\
\hline Tbilisi & 1 & 2 & 1 & 4 \\
\hline Imereti & & & & \\
\hline Kakheti & 4 & 1 & & 5 \\
\hline Samegrelo- Upper Svaneti & & & & \\
\hline Samtskhe- Javakheti & & 4 & 96 & 100 \\
\hline Kvemo Kartli & 80 & 4 & 20 & 104 \\
\hline Total & 85 & 11 & 117 & 213
\end{tabular}

Article 35.1 of the Constitution of Georgia protects the right of every citizen to receive education and to choose the form of education. The law on "General Education" reaffirms this right to education (Article 9) and the "equal access for all" (Office of State Minister For Reconcilation and Civic Equality, Assessment Report, 2014). According to the Law on General Education, schools are responsible for providing students with an education based on universal values of democracy and equality (Article 33.1. A.). This is more widely discussed in the document on National Education Objectives and Curriculum of Various Subjects, approved on October 18, 2004

The Law on General Education covers the cultural diversity of the country and determines Abkhazian as a state language for Autonomic Republic of Abkhazia, (Article 4). .' The same article (Article 4.3) states that 'the citizens of Georgia, to which Georgian is not a native language, have the right to receive full general education in their native language. .". Article 7 of the Law on General Education entitles the students to receive the education in their native language in the closest proximity to their place of residence (Tabatadze and Gorgadze, 2014). The National Curricula of Georgia underlines the importance of multilingualism, particular the general part of the curriculum indicates multilingual, plurilingual competence in a student, among nine other cross-curricula competences that the education system needs to develop:

"Multilingual

(competence.

Multilingual competence is the inner ability to acquire and use languages. A pupil in any subject acquires knowledge and skills through linguistic activities. Accordingly, all subjects may contribute to the 
development of the student's multilingual competence."

\section{National Curricula and Textbooks Reform and Non-Georgian Schools}

The school textbooks are provided in minority languages for non-Georgian schools (Tabatadze, 2010 a) . The development of school curricula and textbooks consists of three stages: 1) development of a curriculum; 2) curriculum piloting; and 3) implementation of the curriculum (Tabatadze, 2009) . The national secondary education curriculum was prepared in 2004 and 2005. The curriculum was piloted in 100 Georgian, ten Russian, ten Armenian, and ten Azeri schools. In 2006-07 the national curriculum was introduced in all Georgian schools of the country; in 2007-08 it was adopted by non-Georgian schools (Tabatadze, 2009). The new textbooks developed based on new National Curriculum were translated for non-Georgian schools. Textbooks were translated into Abkhaz, Ossetian, Russian, Armenian and Azeri languages: for Grades I-VI and $\mathrm{X}$ at the first stage, and for Grades II-VIII and XI at the second stage. Books have been translated for I, II, III, VII, VIII, IX, XI, XII grades (Public Defenders Office, Monitoring Report, 2012) . During the 2009-2010 academic year, within the "textbooks for the nonGeorgian language sector pupils, improvement of accessibility sub-program," the Ministry of
Education and Science distributed bilingual history and geography textbooks free of charge for pupils of the $7^{\text {th }}, 8^{\text {th }}, 10^{\text {th }}, 11^{\text {th }}$ and 12 th classes. Additionally, the "Georgian as a second language textbooks" were given, free of charge, to all non-Georgian language school pupils in grades I-IV (Public Defenders Office, Monitoring Report, 2012).

The Ministry of Education and Science revised the National Curriculum developed in 2005 and adopted new National Curiculum in 2011 for 2011-2016. The new textbooks were developed based on new curicula in 2011 and introduced in public schools for 2011-2016 academic years. New curriculum and new textbooks were introduced in 2011 Ministry of Civil Equality and Reconciliation, Assessment Report, 2014). The introduction of a new curriculum and new textbooks for grades 1-6 in non-Georgian language schools began in the 2012-2013 academic year and schools were provided with translated textbooks. However, the translation approach was changed. Textbooks became bilingual. $70 \%$ of content of textbooks were translated in minority languages and $30 \%$ of content were left in Georgian language. Introducing the new curriculum and textbooks to 7-12 grades was to be implemented for the 2013-2014 school year (Office of State Minister For Reconcilation and Civic Equality, Assessment Report, 2014); However, the Ministry of Education and Science failed to translate and provide these textbooks to schools 
in the 2013-2014 academic year. Accordingly, non-Georgian language schools are still working with old curriculum and textbooks in 2013 (Office of State Minister For Reconcilation and Civic Equality, Assessment Report, 2014).

\section{Research Methodology}

The following research methods were utilized in the study: (a) Desk Research; (b) Focus group discussions; The research used various sources for desk research including: the Constitution of Georgia, laws passed by the Georgian Parliament, international legal documents signed by Georgia, reports and statistical data, materials from the State Minister's Office for Reconciliation and Civil Equality, the National Strategy and Action Plan for Tolerance and Civic Integration, annual reports $(2009,2010,2011,2012)$ of the National Strategy and Action Plan for Tolerance and Civic Integration, the annual reports of the Public Defender and Assessment Document on the implémentation of the national concept for tolerance and civic Integration and action plan for 2009-2014 of Office of State Minister for Reconciliation and Civil Equality . Focus group meetings (a total of 4 focus groups were conducted in Kvemo Kartli and SamtskheJavakheti regions of Georgia) with representatives of non-governmental organizations, school principals, school teachers, parents and active members of the community. The focus group discussions were conducted based on in advance prepared protocol for focus group discussions.

\section{Research Results}

The focus group discussions revealed very important patterns and challenges of schools textbooks for minority textbooks. The challenges can be classified and discussed in three main topics: (a) the problem of quality of translation of school textbooks; (b) stereotyped material is often observed in the textbooks, diversity of Georgia and intercultural aspects are not reflected in school textbooks. Some paragraphs in schools textbooks contain discriminative elements toward different minorities and some of the information is distorted, (c) The portion of the material in the state language in bilingual textbooks is difficult for pupils to understand because neither the students and teachers nor parents speak the state language well enough to incorporate the material in teaching and learning process. Hence, in many cases teachers are simply leaving out the material in the state-language. All three problems revealed during the research will be discussed in details. 
Textbooks Need Improvement in

\section{Intercultural Terms}

It should be noted that according to Order №072 issued on March 30, 2009, by the National Curriculum and Assessment Center which determines the use of textbooks, and the accompanying instruction manual on the evaluation criteria for the textbooks, it was noted that: "d) the content of the textbooks should take into consideration the diversity of Georgian students on the basis of race, color , language, sex, religion, political or other opinion, national, ethnic or social origin , property or social status, as well as place of residence (Tabatadze, 2010b)." In the 2011 approval of textbooks, the requirement for the reflection of Georgia's diversity and the spread of non-stereotypical views was removed. There was an article in the rule which stated that approval for use would not be issued to textbooks where "the content, design or any other sign contains discriminatory elements (on the basis of language, nationality, ethnic or social origin, etc.) but it was not reflected in the textbook evaluation criteria. This article had been removed completely in the 2011 approval criteria for textbooks. Hence, this rule does not apply to the approval of textbooks for grades 16. It should be noted that the article was only added during the 2012 Amendment: on January 6, 2012, by order of the Minister of Education and Science, the rule came into effect for the approval process of 7-12 grade textbooks, but in practical terms the effect was not that large (a detailed analysis of textbook problems in regards to intercultural issues can be seen in the study on "The aspects of intercultural studies in Georgia's primary education")

Various studies have shown that primary and secondary school textbooks, in some cases do not reflect the country's ethnic and religious diversity, and are not free from the stereotypical tendencies. Below is an extracts from one of studies of schools textbooks (Tabatadze et al):

"Georgia's Ethnic and religious diversity is not properly reflected in the textbook. To illustrate, the textbook starts with a text Our Motherland Georgia. The text describes different parts of Georgia and their traditions: "Georgia is famous for its diverse traditions. People from different parts of Georgia - Gurians, Svans, Mingrelians and Kakhetians, Mtiuls, Mokhevians and Pshavels, Ajarians and Khevsurs, Imerians and Tushes, Lechkhumians and Meskhs, Rachians and Kartlians are different by their living environment, traditions, dialect, songs and dances. There is one thing that unites parts of this one small country - this is their historic achievement - one united state - 
Georgia “. Thus, the text does not mention ethnic diversity of the country, neither the ethnic groups are represented as part of the Georgian state. The text is ethnocentric and shows loyalty to Georgian ethnic group and fully ignores non-Georgian ethnic groups as part of the Georgian state (p.44)

Below is the extract from the same study on textbook "Our Homeland, Grade 5 (Tabatadze et al, p59):

Authors of the textbook describe the population of Kvemo Kartli with the following statements: Due to various reasons, Kvemo Kartli was populated not only by Georgians but also by such ethnicities as Azerbaijanians, Armenians, Greeks, and Germans... The situation has significantly changed by now. Due to the recent natural disasters in their native languages, many families from Svaneti and Adjara and settled in this region" ( $p$. 71). Description of Kvemo Kartli population is characterized with certain discriminative elements. The statements used may form negative attitudes towards different ethnic groups and lead students not to consider them as citizens of Georgia. The same pattern is observed in the description of Javakheti population.
The authors are presenting historical facts only. However, existing statements do create the danger of discrimination of ethnic minorities. For almost three hundred years Javakheti was invaded by Osmals (Turkey). Part of the population settled in Kartli. The rest were forced to convert to Islam. Approximately 180 years ago after defeating Turkey, Russia re-joined Javakheti. It forced Islam population to move to Turkey and replaced them by ethnic Armenians. Today Georgian population lives only in few villages of Javakheti. Similar to the description of Kvemo Kartli population, this description contains discriminative elements and may form negative attitudes towards different ethnic groups. This discriminative elements get even stronger if the full history of settling Armenian population in Javakheti. According to the information provided by authors as cited above, Armenians were brought to Georgia 180 years ago to replace Georgians

The authors of above-mentioned study concluded, that: “... majority of the textbooks encourage and perpetuate stenotypes among the students in different directions, namely by territorial settlement, socio-economic status, health and abilities, gender, etc. Also, it should be noted that most of the textbooks do not reflect ethnic, religious, territorial settlement 
diversity of Georgia and is written with ethnocentric perspective. Therefore, they may fail to develop intercultural sensitiveness and tolerance among the students (Tabatadze et al, p.89).

The issues related to the reflection of intercultural aspects in textbooks are especially important - on the one hand in terms of creating an anti-discriminatory learning environment for minority students, and on the other hand to engrain intercultural sensitivity and tolerance in students of the majority, an aspect which is essential for the civil integration process where the wish for integration from minorities is just as important as the high level of acceptance from the majority (Tabatadze, 2014). Consequently, reflection of intercultural and interreligious issues in textbooks remains to be an acute problem. Focus group discussions also revealed some specific examples regarding the problem:

There are lots of errors in depicting historical facts. E.g. Albanian historian is mentioned as Armenian historian...; ...Textbooks say that Mohamed was a fortuneteller instead of prophet which is a real insult.

\section{The Problem of Quality of Textbook}

\section{Translation into Minority Languages}

The process of translation into minority languages in Georgia began in 2005 and has continued systematically for both the curriculum and textbooks. In this regard, there is a constant discussion on the poor quality of translation, especially of Armenian and Azerbaijanian textbooks. There is an improvement in translation visible every year. It should be noted that since 2011 the Council of National Minorities under the Public Defender's Office has been involved in the editing process of translated textbooks for grades 1-6. Unfortunately, since 2012, this process has failed to expand into the other grades as the Ministry of Education and Science and the Public Defender's Office, along with publishing houses, did not carry out the translation of textbooks for grades 7-12. During the focus groups conducted in Akhalkalaki and Ninotsminda the problem of qquality of textbooks' translation has been again identified by the participants of focus group discussions as one of the major problems. In their opinion, textbooks are not edited, corrected and therefore there are lots of errors. Below are some quotes from focus group discussions:

Example: Rome is built on the River Tiber. Authors decided that the letter "B" is not correct and have written that Rome is built on the River Tigris that is in Mesopotamia." Teachers in all districts of Kvemo Kartli and Samtskhe-Javakheti regions talk about the errors in translated textbooks. Errors and inaccuracy in the 
textbooks cause dissatisfaction among teachers and schoolchildren.

We do not like quality of translation, there are too many errors. For example, in math textbook instead of word "calculation" we can see the word "transaction" which is certainly obvious mistake for a teacher. It seems that translated textbooks did not go through mathematician; otherwise, it is impossible to witness such explicit errors and inaccuracy. However, this is not a great problem in Math per se since figures and signs are the same in every language."

\section{The Problems with Bilingual Textbooks}

The translation process of textbooks has changed since 2011. According to the Ministry's decision, only $70 \%$ of the material in textbooks is translated, while the remaining $30 \%$ is left in the state language. The purpose of this initiative was to promote bilingual education reform, but this initiative was carried out with serious flaws:

1. The $70 \%-30 \%$, translation principle of textbooks is not based on any scientific and methodological evidence and does not correspond to any learning principle on the integrated study of subjects. Accordingly, the mechanical procentile division turned out to be absolutely ineffective and to have only a negative affect;

2. Subject teachers who do not speak the state langusage are unable to use the textbooks properly, since they don't understand the content of the $30 \%$ of the textbooks left in the state language;

3. The parents of students attending nonGeorgian language schools are unable to assist their children, since they do not understand the material in the existing textbooks;

4. In many cases, the translation is so illogical in its distribution that it cannot be understood by the pupils, parents, and teachers and thus often both the material in their native language and the state language is left unlearned.

According to the participants of focus group discussions, it is good that the state provides translation of textbooks. However, at this point teachers are not ready to fully use bilingual textbooks in the classroom.

„Even teachers of Georgian language do not know enough Georgian not to say anything about teachers of other subject areas whose competence in Georgian language is extremely poor. In this circumstance, certainly it is difficult for teachers to use a textbook where $30 \%$ of the material is given in Georgian." 
Teachers and other participants of focus group had greater complains toward the textbooks of History and Geography. There have been many controversies about these textbooks. In bilingual textbooks, in which most of the materials are given in minority languages, some parts (especially citations from direct sources) are given in Georgian. Teachers believe that pupils and teachers are not ready to teach and learn with bilingual textbooks. Majority of history and geography teachers does not know Georgian. Schools either do not have a qualified Georgian language teacher who can help geography and history teachers in comprehending given material during the teaching process. Therefore, teaching process with these textbooks is hampered. Those schools where there are qualified Georgian language teachers or a teacher assigned in the framework of "Qualified Georgian Teachers Programme" face fewer problems in this regard, since in this case a teacher of Georgian language can provide translations into Georgian for subject area teachers or pupils.

„The most challengeable is the fact that the sources which should be found by a schoolchild independently are given in Georgian. Therefore, a child is not able to prepare lessen if she/he does not know Georgian or a teacher does not provide translation of sources or additional materials..."
The focus groups conducted in Akhalkalaki, Ninotsminda and Marneuli identified the following solutions to the existing problems in terms of the bilingual translation of textbooks:

1. Teachers are using the textbooks from the previous year in subjects where such textbooks are available. However, often there are certain chapters in the current textbook that are not included in last year's textbooks so the teachers request assistance from their colleagues to comprehend the sections written in Georgian;

2. Teachers use textbooks imported from neighboring states that exist in their school libraries and became useful after the application of the $70 \%-30 \%$ translation method;

3. They have been translating the Georgian portions of textbooks with the help of Georgian language teachers in schools;

4. Teachers just leave out and do not explain (and don't give homework on) the material in Georgian.

\section{Conclusion}

The research findings have an important implication for Georgian educational system. The research results can be considered in future policy of school textbook development for minority schools. Based on research findings, it 
is crucially important to make the following policy changes for improvement of school textbooks for minority schools, specifically: (a) It is important for school textbooks to reflect the diversity of Georgia and not to contain stereotypical and discriminatory elements. Accordingly, the Ministry should take steps to revise National Curricula as well as, Textbook Approval and Textbook Evaluation rule; (b) It is important that the Ministry of Education and Science establishes a reformed concept of multilingual education and that it develops a related implementation strategy and action plan; Bilingual editions of textbooks should be revised and effective mechanisms developed in this direction which will result in the provision of language teaching improvement, and at the same time, the effective perception of subject content. The improved bilingual textbooks have to promote the reform of content and language integrated learning in non-Georgian schools; (c) The additional mechanisms should be introduce for assurance of quality of translation of school textbooks in minority languages.

To conclude, ineffective bilingual approaches and bilingual textbooks may even become a barrier for a language acquisition, as well as for overall academic achievement of minority students. Therefore, it is very important for the educational institutions to develop and implement effective bilingual educational approaches and strategies in order to take the advantage of the strengths of bilingualism in Georgia (Tabatadze, 2014).

\section{References:}

Gabunia, K. (2014a) Language Situation in Modern Georgia 1. Kartvelian Languages. International Journal of Multilingual Education, 2 (1), p 13-34

Gabunia, K.(2014b) Language Situation in Modern Georgia 2. Caucasian and Non-Caucasian Languages. International Journal of Multilingual Education, 2 (2), p. 1-21.

Gorgadze, N. \& Tabatadze, S. (2014). Analysis of the development of lifelong learning and regional action plan for promoting efficient educational management; Tbilisi; Caucasus University Fund

Government of Georgia (2009) National Concept for Tolerance and Civil Integration and Action Plan for 20092014 retrieved on March, 22, 2015 from the web-site: http://www.smr.gov.ge/docs/doc43.pdf

Ministry of Education and Science of Georgia. (2009) The rule of school textbook approval. Tbilisi

Ministry of Education and Science of Georgia. (2010) The rule of school textbook approval. Tbilisi

Ministry of Education and Science of Georgia. (2011) The rule of school textbook approval. Tbilisi

Ministry of Education and Science of Georgia. (2012) The rule of school textbook approval. Tbilisi 
National Curriculum and Assessment Centre. (2011). National Curriculum of Georgia 2011-2016. Retrieved http://www.mes.gov.ge/content.php?id=3929\&lang=geo.

Office of the State Minister of Georgia for Reconcilation and Civil Equality (2014). Assessment document on the implementation of the national concept for tolerance and civic Integration and action plan for 2009-201, retrived on March 22, 2015 from the web-site: http://www.smr.gov.ge/docs/doc329.pdf

Parliament of Georgia (2005) Georgian Law on General Education retrieved on June 25. 2013 from the web-site: www.parliament.ge

Parliament of Georgia (1995) Constitution of Georgia, retrieved on June 25. 2013 from the web-site: www.parliament.ge

Public Defenders Office of Georgia (2012) Monitoring results of implementation of the National Concept and Action Plan on Tolerance and Civil Integration in 2010-2011. Retrieved on March 22, 2015 from the website: http://www.ecmicaucasus.org/upload/cnm/UNDP-Publication-ENG-FINAL.pdf

Tabatadze, S. Gabunia, K. \& Odzeli, M. (2008). Recomendaciones on language policy to protect linguistic minorities. Tbilisi: Centre for Civil Integration and Inter-Ethnic Relations

Tabatadze, S. (2009). The reform of education system of Georgia and non-Georgian language schools. Tbilisi: Caucasus Institute for Peace, Democracy and Development.

Tabatadze, S. (2010b). Intercultural education in Georgia. In Culture dialogue and civil consciousness (pp. 6386). Tbilisi: Caucasus Institute for Peace, Democracy and Development

Tabatadze, S. (2010 b). New initiatives of education policy in the context of civil integration. Tbilisi: Caucasus Institute for Peace, Democracy and Development.

Tabatadze, S. (2011). Bilingual educational policy in Georgia. In Human diversity in education, integrative approach (pp. 282-284). New York: McGraw-Hill.

Tabatadze, S., Gorgadze, N., Gabunia, K., Khomeriki, I., \& Tinikashvili, D. (2013) Intercultural Education Research in Primary Grades of Georgia. Tbilisi: Centre for Civil Integration and Inter-Ethnic Relations

Tabatadze, S., \& Gorgadze, N. (2014). Intercultural sensitivity of primary school teachers of Georgia. International Journal of Education and Research, 6, 281-300

Tabatadze,S. (2014) Positive Effects of Bilingualism on Cognition and Language Acquisition. International Journal of Multilingual Education, 2 (1).1-12

Tabatadze, S. (2015). Factors Influencing the Effectiveness of Bilingual Educational Programs: The Prospects of Pilot Programs in Georgia. Sino-US English Teaching, 12 (2), 93-109.

United Nations Association of Georgia. (2010). Monitoring Results of Implementation of the National Concept and Action Plan on Tolerance and Civic Integration 2007-2009 Tbilisi; UNAG. 